(C) The Authors 2017. This is an Open Access article, distributed under the terms of the Creative Commons Attribution licence (http://creativecommons.org/licenses/by/4.0/), which permits unrestricted re-use, distribution, and reproduction in any medium, provided the original work is properly cited.

\title{
Resveratrol and inflammatory bowel disease: the evidence so far
}

\author{
Sandra Nunes ${ }^{1}$, Francesca Danesi ${ }^{2}$, Daniele Del Rio ${ }^{3 \dagger}$ and Paula Silva ${ }^{1}{ }^{* \dagger}$ \\ ${ }^{1}$ Laboratory of Histology and Embryology, Institute of Biomedical Sciences Abel Salazar (ICBAS), University of Porto, Rua de \\ Jorge Viterbo Ferreira 228, 4050-313 Porto, Portugal \\ ${ }^{2}$ Department of Agri-Food Science and Technology (DISTAL), University of Bologna, Piazza Goidanich, 60-47521 Cesena, Italy \\ ${ }^{3}$ Laboratory of Phytochemicals in Physiology, Human Nutrition Unit, Department of Food and Drugs, University of Parma, Via \\ Volturno, 39-43125 Parma, Italy
}

Abstract

Despite the fact that inflammatory bowel disease (IBD) has still no recognised therapy, treatments which have proven at least mildly successful in improving IBD symptoms include anti-inflammatory drugs and monoclonal antibodies targeting pro-inflammatory cytokines. Resveratrol, a natural (poly)phenol found in grapes, red wine, grape juice and several species of berries, has been shown to prevent and ameliorate intestinal inflammation. Here, we discuss the role of resveratrol in the improvement of inflammatory disorders involving the intestinal mucosa. The present review covers three specific aspects of resveratrol in the framework of inflammation: (i) its content in food; (ii) its intestinal absorption and metabolism; and (iii) its anti-inflammatory effects in the intestinal mucosa in vitro and in the very few in vivo studies present to date. Actually, if several studies have shown that resveratrol may down-regulate mediators of intestinal immunity in rodent models, only two groups have performed intervention studies in human subjects using resveratrol as an agent to improve IBD conditions. The effects of resveratrol should be further investigated by conducting well-designed clinical trials, also taking into account different formulations for the delivery of the bioactive compound.

Key words: Inflammation: (Poly)phenols: Inflammatory bowel disease: Grapes: Resveratrol: Stilbenes

Introduction

Inflammatory bowel disease (IBD) is the generic term used to describe a group of chronic diseases characterised by uncontrolled inflammation of the intestinal mucosa ${ }^{(1)}$. The aetiology of IBD is currently unknown. However, IBD progression is influenced by genetic factors, dysregulation of immune responses, dysfunction of the mucosal barrier, and loss of immune tolerance to enteric flora ${ }^{(2)}$. Altogether, these factors result in the production of inflammatory mediators such as oxygen and nitrogen reactive species, prostaglandins and cytokines, which can contribute to an uncontrolled inflammatory response that ultimately culminates in irreversible tissue damage. The two main forms of IBD are Crohn's disease and ulcerative colitis (UC), each differing in location and severity. Crohn's disease is known to affect multiple sections of the gastrointestinal tract, whereas UC is limited to the rectum and colon $^{(3,4)}$. Furthermore, IBD patients with an extended history of the disease maintain a high risk of developing colon cancer ${ }^{(5)}$. A greater understanding of the pro-inflammatory cytokine networks underlying enteric mucosa inflammation has led to the development of targeted anti-TNF- $\alpha$ therapies. Additionally, recent studies have been aimed at exploring novel treatments for IBD, including regulatory $\mathrm{T}$ cell therapy, the use of anti-inflammatory cytokines - for example, IL-10 - and stem cell-based therapies ${ }^{(6,7)}$. Previous epidemiological studies have identified a correlation between the consumption of red wine and a decreased incidence of heart disease, known as the 'French paradox' ${ }^{(8)}$. This correlation might be due to the presence of resveratrol, a known antioxidant, anti-inflammatory, and anti-proliferative compound, in red wine ${ }^{(9)}$. In vitro and in vivo studies have also shown that resveratrol ameliorates IBD by decreasing mucosal inflammation ${ }^{(10)}$.

In the present review, we will discuss the effects of resveratrol on IBD pathology, and - by reviewing data from in vitro, animal and human studies - we will describe the mechanisms utilised by resveratrol that mediate its anti-inflammatory activity. We will begin by characterising the natural occurrence and biosynthesis of resveratrol, followed by describing its metabolism. Finally, we will focus on how resveratrol improves the prognosis in patients with IBD.

\section{Resveratrol occurrence and synthesis}

Resveratrol (3,4',5-trihydroxystilbene) is a naturally occurring stilbene found in a variety of plant species (for example, grapes,

Abbreviations: BCRP, breast cancer resistance protein; COX-2, cyclo-oxygenase-2; DSS, dextran sulfate sodium; IBD, inflammatory bowel disease; miRNA, microRNA; MRP, multidrug resistance protein; SphK1, sphingosine kinase 1; STAT, signal transducer and activator of transcription; Th17, T helper 17 cells; TNBS, 2,4,6-trinitrobenzenesulfonic acid; UC, ulcerative colitis.

* Corresponding author: Dr Paula Silva, email psilva@icbas.up.pt

$\dagger$ These authors contributed equally to the present study. 
groundnuts, Japanese knotweed, and several species of berries, such as blueberries, bilberries and cranberries), and exists as both cis-and trans-isomers, the latter being the most commonly found and stable form ${ }^{(11)}$. The compound was first isolated in 1940 from white hellebore (Veratrum grandiflorum O. Loes) ${ }^{(12)}$ and, in 1963, was found in Japanese knotweed (Polygonum cuspidatum), currently one of the principal sources of resveratrol found in nature ${ }^{(13)}$. In 1976, Langcake \& Pryce ${ }^{(14)}$ detected, for the first time, trans-resveratrol in grapevines (Vitis vinifera), where resveratrol is synthesised in response to exogenous stimuli such as fungal damage (for example, Botrytis cinerea) or UV light. Resveratrol was later found to be highly photosensitive and susceptible to UV-induced isomerisation, as more than $80 \%$ of trans-resveratrol in solution is converted to cis-resveratrol if exposed to light for $1 \mathrm{~h}^{(15)}$. The final step of resveratrol biosynthesis involves stilbene synthase-mediated condensation of three molecules of malonyl-CoA with one molecule of $p$-coumaroyl acid, generating trans-resveratrol and four molecules of $\mathrm{CO}_{2}{ }^{(16)}$ (Fig. 1). In the 1990s, resveratrol was identified as a component of red wine ${ }^{(17)}$ and, since then, it has been studied extensively. In 2013, Tomé-Carneiro et al. ${ }^{(18)}$ estimated more than 22500 publications on resveratrol in three databases of literature (PubMed, Scopus, ISI Web of Knowledge). Resveratrol is produced especially in the skins of grapes $^{(19)}$, and it is extracted in the maceration process during the production of red wine ${ }^{(20)}$. The amount of resveratrol present in red wine is influenced by grape variety, soil, climate and winemaking techniques, including manipulation of the amount of time that grape skins remain during the fermentation process $^{(17,21)}$. Resveratrol occurs in wine both in its unconjugated, aglycone, form and as resveratrol glucoside (resveratrol3 -O- $\beta$-D-glucoside, often referred to as piceid), both in cis and trans arrangements ${ }^{(22,23)}$. The concentration of piceid is approximately three times higher than that of aglycone resveratrol in wines originating from Spain and Portugal ${ }^{(24,25)}$.

\section{Absorption, bioavailability and metabolism of resveratrol}

It has been previously demonstrated that phenolic compounds, present in the plasma at low (nanomolar to micromolar) concentrations, are found in the intestine at much higher levels immediately after the consumption of foods and supplements rich in these compounds ${ }^{(26)}$. Thus, phenolic compounds may play a pivotal role in the modulation of the colon microenvironment in both healthy and pathological conditions ${ }^{(27,28)}$. Likewise, resveratrol has a rapid rate of uptake and is absorbed in large quantities by enterocytes. However, plasma concentrations of resveratrol are generally low due to high rates of intestinal and hepatic metabolism ${ }^{(29)}$. In one study, the maximum plasma concentration $\left(\mathrm{C}_{\max }\right)$ of resveratrol, evaluated in human subjects following administration of a high concentration of resveratrol, was found to be within the range of 0.3 to $2.4 \mu \mathrm{mol} / \mathrm{l}$ after approximately $1.5 \mathrm{~h}$. Here, the authors described two main types of resveratrol metabolites, resveratrol-3sulfate and resveratrol monoglucuronides, that were found in the plasma at concentrations of up to about 20-fold higher than that of resveratrol itself ${ }^{(30)}$.<smiles>N[C@@H](Cc1ccccc1)C(=O)O</smiles>

L-Phenylalanine<smiles>O=C(O)/C=C/c1ccccc1</smiles>

trans-Cinnamic acid<smiles>O=C(O)/C=C/c1ccc(O)cc1</smiles><smiles>O=C(OCc1ccc(O)cc1)OC(=O)SC(=O)O</smiles>

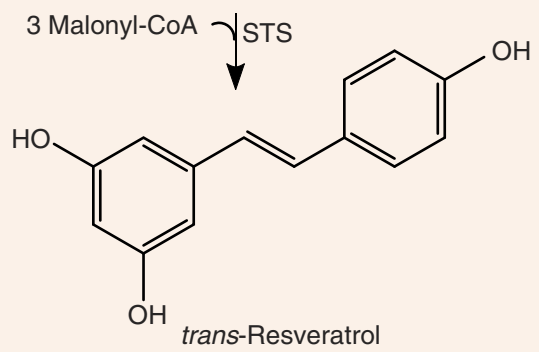

Fig. 1. Synthesis of resveratrol. PAL, phenylalanine ammonia-lyase; $\mathrm{C} 4 \mathrm{H}$, cinnamate 4-hydroxylase; 4CL, 4-coumarate-CoA ligase; STS, stilbene synthase.

Previous studies have also characterised the rate of uptake of resveratrol in vitro and in vivo. Resveratrol, upon entering the small intestine, crosses the enterocyte apical membrane by either passive diffusion or carrier-mediated transport. The aglycone form of resveratrol is absorbed by passive diffusion into human epithelial colorectal adenocarcinoma cells (Caco-2) across the apical membrane, whereas the piceid form is actively transported via Na-dependent transporter proteins ${ }^{(31)}$ (Fig. 2). The transepithelial transport of piceid occurs at a higher rate compared with the aglycone form of resveratrol ${ }^{(32)}$. Nevertheless, piceid is then hydrolysed by $\beta$-glycosidases that are produced by the intestinal microflora, promoting the absorption of the aglycone form ${ }^{(33)}$. Phase II metabolism of 

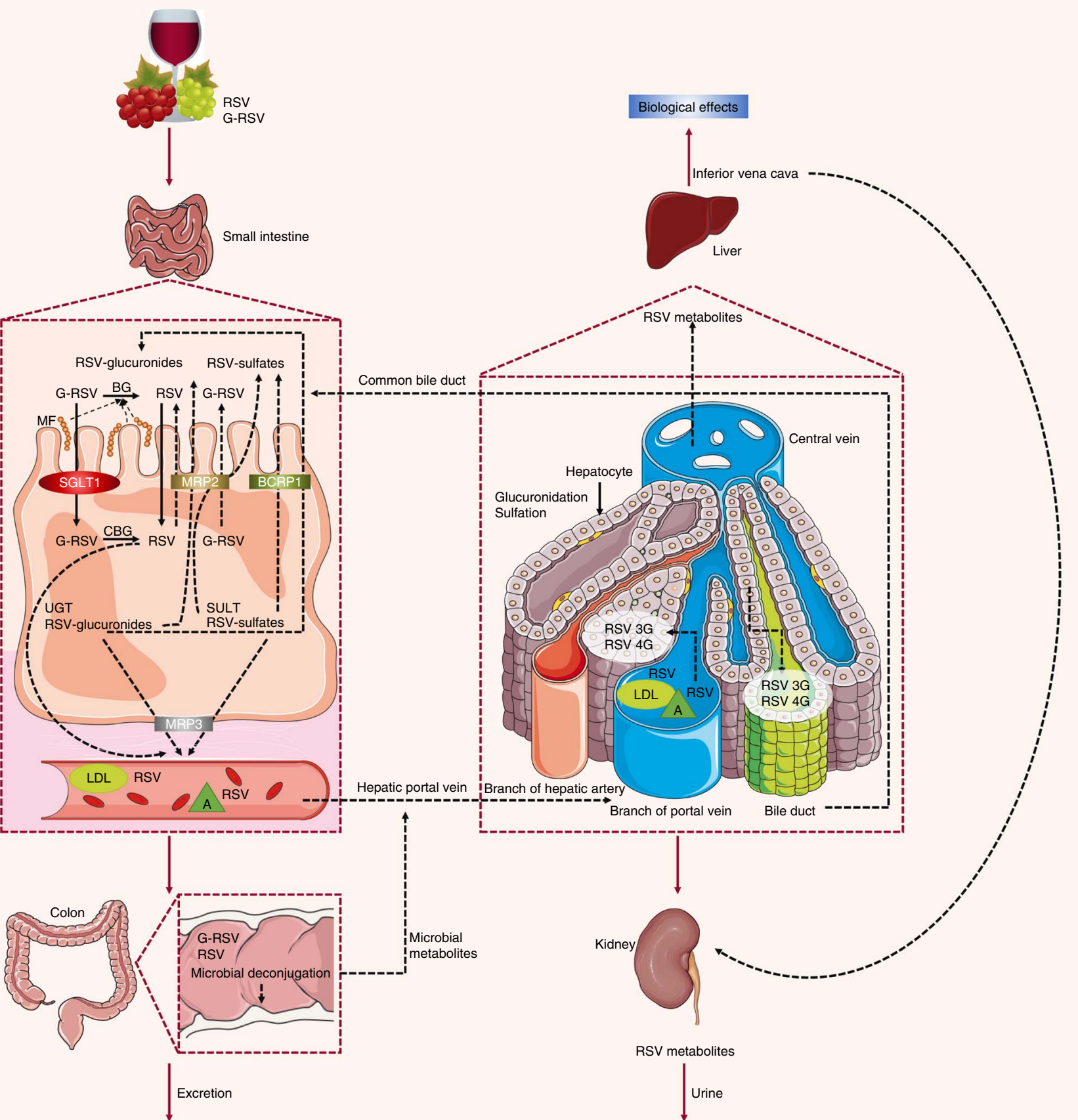

Fig. 2. Absorption and metabolism of resveratrol. After ingestion, resveratrol may be absorbed as glycoside (G-RSV) and then cleaved to the aglycone form of resveratrol (RSV) by cytosolic glucosidase (CBG). Alternatively, this process can occur in the lumen with the action of $\beta$-glycosidases (BG) produced by the intestinal microflora (MF). Within enterocytes, RSV is rapidly metabolised to resveratrol glucuronides (RSV-glucuronides) and resveratrol sulfates (RSV-sulfates) via uridine-5'diphosphate-glucuronosyltransferase (UGT) and sulfotransferase (SULT), respectively. There is some efflux of these metabolites back into the small intestine, which involves multidrug resistance protein (MRP) 2 and breast cancer resistance protein (BCRP) 1. Resveratrol conjugates can also efflux though the basal side of the enterocytes via MRP3. RSV can passively diffuse through the enterocyte basal membrane. Once in the bloodstream, resveratrol and its metabolites reach the liver, where they are further glucuronidated or sulfated. Resveratrol and its conjugates can be recycled back to the small intestine through the bile or excreted via urine. SGLT1, sodium-dependent glucose cotransporter-1; A, albumin.

resveratrol occurs in the gut, where resveratrol is conjugated with sulfate by sulfotransferase or with glucuronic acid by uridine-5'-diphosphate-glucuronosyltransferase, yielding metabolites resveratrol sulfates and resveratrol glucuronides, respectively ${ }^{(34,35)}$. Three derived metabolites have been identified: resveratrol-3-glucuronide, resveratrol-4'-O-glucuronide and resveratrol-3-O-sulfate. In addition, intestinal bacteria are able to convert resveratrol to dihydroresveratrol, which is also transported into enterocytes and metabolised to sulfated or glucuronidated forms ${ }^{(35,36)}$. 
In an ex vivo study using an isolated rat small intestine perfusion model, Andlauer et $a l{ }^{(37)}$ showed that $46 \%$ of the luminally administered resveratrol was absorbed by the small intestine, $21 \%$ of which appeared in vascular tissue while another $2 \%$ was located inside the intestine. In the luminal effluent, $40 \%$ of resveratrol was unconjugated, $11 \%$ was glucuronidated, and 3\% was sulfated. Here, a likely explanation for the presence of resveratrol conjugated metabolites in the intestinal lumen is the presence of apically located efflux transporters ${ }^{(38)}$, such as multidrug resistance protein (MRP) 2, MRP3 and breast cancer resistance protein (BCRP) 1, which are all present in the membrane of the enterocytes ${ }^{(39)}$. MRP3 is present in the basolateral membrane of enterocytes, whereas BCRP1 is present in the apical membrane ${ }^{(40)}$. When BCRP1 is inhibited, the efflux of resveratrol glucuronide and sulfate conjugates is diminished without affecting the absorption of resveratrol. BCRP1 is the most important efflux transporter for sulfate conjugates, as evidenced in BCRP1 knockout mice, where sulfate and glucuronide metabolite efflux was inhibited by 95 and $70 \%$, respectively ${ }^{(41)}$. Glucuronidated resveratrol is also a substrate of $\mathrm{MRP}^{(31)}$. Kaldas et $a l^{(34)}$ showed that treatment with low concentrations of resveratrol resulted in the production of resveratrol metabolites primarily on the apical side of Caco- 2 cells. On the other hand, using high concentrations of resveratrol, sulfate conjugates were exported towards the basolateral side, where the MRP3 transporter is localised, due to the saturation of transporters on the apical side. Therefore, the trans-resveratrol conjugates that are not transported to the apical side by MRP2 and BCRP1 are transported by MRP3 into the bloodstream ${ }^{(42)}$. There, the metabolites are hydrolysed and converted back into an aglycone form by the intestinal microflora, and the excreted compounds can be reabsorbed back into the interior of the enterocytes ${ }^{(38)}$.

Once resveratrol has been metabolised by intestinal epithelial cells, it is transported to the liver and enters hepatocytes by passive and carrier-mediated transport ${ }^{(41)}$. After crossing the hepatocyte membrane, resveratrol is rapidly conjugated and metabolised into its glucuronidated and sulfated derivatives ${ }^{(43)}$. All forms of resveratrol are then subsequently excreted in the bile ${ }^{(44)}$.

In the blood, transport of resveratrol is accomplished through its association with lipoproteins, $\mathrm{Hb}$, albumin and serum proteins as it is carried to and from various organs and tissues, followed by elimination in the urine ${ }^{(45)}$.

Because resveratrol is extensively metabolised in the gastrointestinal tract and the liver, it will be crucial for future studies to determine if the biological beneficial effects mediated by resveratrol are due not only to the parent compound but also to their metabolites, as has been suggested by Aragonès et $a l .{ }^{(46)}$ (for a full review, see Del Rio et $a l .{ }^{(47)}$ ).

\section{Effects of resveratrol on inflammation and inflammatory bowel disease \\ Inflammatory bowel disease pathophysiology}

The intestinal wall is protected by epithelial cells attached via tight junctions that form a seal against the lumen of the intestinal tract. These epithelia provide a physical barrier between the internal environment and luminal microbes, representing the first line of defence of mucosal immunity ${ }^{(48)}$. Impairment of this barrier, due to the dysregulation of tight junctions, leads to increases in permeability and infection ${ }^{(49)}$. Loss of intestinal barrier integrity also promotes abnormal immune and inflammatory responses that are triggered by increased interactions between gut microbiota and the host's immune system, a key factor that precedes UC and Crohn's disease (Fig. 3) ${ }^{(4,50,51)}$.

Luminal microbes that cross the epithelial barrier and multiply within host tissues are recognised by macrophages that reside in the lamina propria of the mucosa. Macrophages act as antigen presenters for $\mathrm{T}$ lymphocytes and are responsible for secreting cytokines and chemokines that attract and activate other immune cells, such as lymphocytes and neutrophils ${ }^{(52)}$. Thus, circulating leucocytes are 'arrested' at the site of inflammation due to the production of selectins and factor VIII by endothelial cells. In these instances, selectins allow for the adhesion of lymphocytes and granulocytes to the target tissue, and factor VIII promotes the activation of the complement pathway and the kinin cascade, thereby increasing intestinal permeability ${ }^{(53)}$. Macrophages and neutrophils represent the primary source of reactive oxygen and nitrogen species present within inflamed colon mucosa ${ }^{(54)}$. These cells have a reduced NADPH oxidase system that leads to the production of an array of reactive oxygen and nitrogen species ${ }^{(55)}$. Once activated, $\mathrm{NADPH}$ oxidase transfers one electron from NADPH to molecular oxygen, yielding one superoxide anion radical $\left(\mathrm{O}_{2}^{{ }^{-}}\right)$. Superoxide radicals are then converted into hydrogen peroxide $\left(\mathrm{H}_{2} \mathrm{O}_{2}\right)$ and the hydroxyl radical $\left(\mathrm{HO}^{\circ}\right)^{(56)}$. IBD patients with intestinal inflammation show elevated levels of reactive species. Consequently, mucosal damage caused by high levels of oxidative stress plays a key role in the pathogenesis of $\mathrm{IBD}^{(57)}$.

The nuclear factor $\kappa$ light-chain-enhancer of activated B cells (NF- $\mathrm{\kappa B}$ ) is an important regulator of immunity that actively participates in the progression of IBD. Once activated, NF- $\mathrm{KB}$ induces the expression of genes involved in inflammation and immunity, such as proinflammatory cytokines (TNF- $\alpha$, IL-1 $\beta$, IL-6, IL-12), adhesion molecules, and enzymes such as inducible NO synthase and cyclo-oxygenase- $2(\mathrm{COX}-2)^{(58)}$. The induction of cytokine expression by NF- $\mathrm{KB}$ is responsible for the stimulation, activation and differentiation of lamina propria immune cells, resulting in persistent mucosal inflammation. For example, TNF- $\alpha$ acts as a positive feedback signal that enhances the production of reactive oxygen and nitrogen species, and NF- $\mathrm{KB}$ activation ${ }^{(59)}$. The uncontrolled production of reactive species in the mucosa appears to play a significant role in IBD disease pathogenesis and is responsible for the onset of IBD-related symptoms, including diarrhoea, toxic megacolon and abdominal pain ${ }^{(60)}$.

Another factor that has been shown to affect the pathology of IBD is the IL-23/T helper 17 cells (Th17) pathway. This pathway contributes to immune responses that regulate intestinal inflammation in both animal models of colitis and human patients with $\mathrm{IBD}^{(61)}$. Importantly, experimental evidence has confirmed the involvement of the IL-12/IL-23 pathway in the pathogenesis of $\operatorname{IBD}^{(62,63)}$.

\section{Effects of resveratrol on inflammation in vitro}

In vitro resveratrol's effects on inflammation are summarised in Table 1. Several groups have previously characterised the 


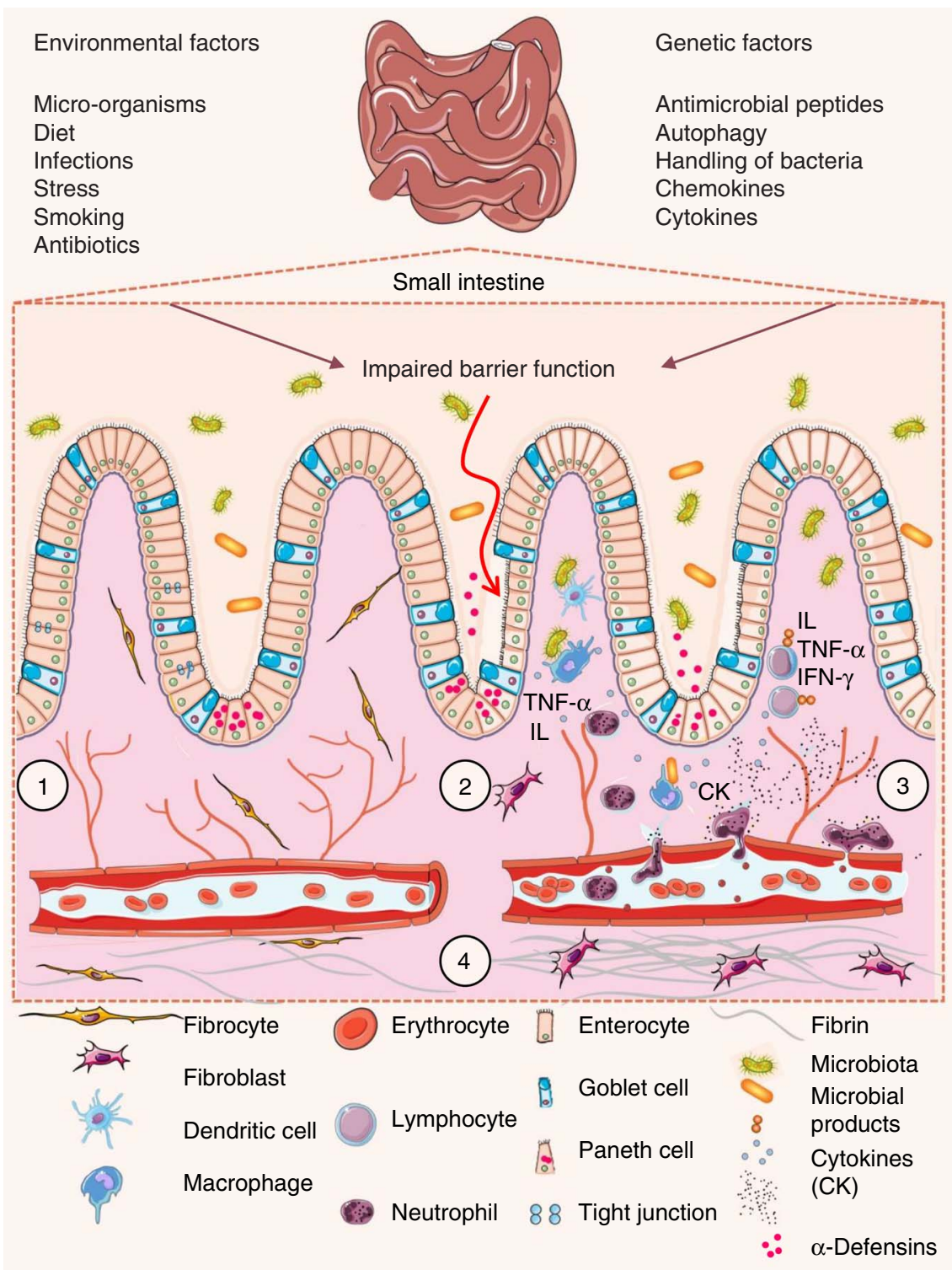

Fig. 3. Pathophysiology of inflammatory bowel disease. (1) The villi and intestinal glands, along with the lamina propria, associated gut-associated lymphoid tissue and muscularis mucosae, constitute the essential features of the small-intestinal mucosa. The glands are composed of a simple columnar epithelium that is continuous with the epithelium of the villi. Intestinal epithelium cells include enterocytes, goblet cells, Paneth cells, enteroendocrine cells and $\mathrm{M}$ cells. Tight junctions in the enterocytes establish a barrier between the intestinal lumen and the epithelial intercellular compartment. (2) Genetic and environmental factors induce the disruption of tight junctions, causing increased permeability of the intestinal epithelium and increased uptake of commensal bacteria and microbial products. The recognition of these by macrophages and dendritic cells leads to immune cell activation and cytokine (CK) production. (3) After activation by macrophages and dendritic cells, T-cells produce various interleukins (IL) and TNF-a. (4) If acute mucosal inflammation cannot be resolved by anti-inflammatory mechanisms, chronic intestinal inflammation develops. In turn, chronic inflammation may cause tissue destruction and complications such as fibrosis, stenosis and cancer. IFN- $\gamma$, interferon $\gamma$.

anti-inflammatory effects of resveratrol in intestinal cells. One study focused on the protective effects of moderate to high concentrations of resveratrol $(10-50 \mu \mathrm{M})$ in Caco-2 cells exposed to bacterial-derived lipopolysaccharides. Here, it was shown that, in resveratrol-treated cells, lower levels of $\mathrm{PGE}_{2}$ correlated with a decrease in COX-2 expression. Furthermore, resveratrol inhibited NF- $\mathrm{KB}$ activation by reducing the rate of degradation of IкB, an endogenous NF-KB inhibitor ${ }^{(64)}$. A similar effect of resveratrol on the activation of NF-kB was observed in Caco-2 cells and SW480 human colon adenocarcinoma cells treated with lipopolysaccharides. High concentrations of resveratrol $(40 \mu \mathrm{M})$ abrogated the inflammatory responses of both cell types by reducing the expression of Toll-like receptor 4 and inducible NO synthase and decreasing the rate of IкB- $\alpha$ degradation ${ }^{(65)}$. Conversely, treatment with resveratrol $(50 \mu \mathrm{M})$ did not inhibit NF-KB activation in a different study that used Caco-2 cells but instead exacerbated inflammatory responses ${ }^{(66)}$.

5-Aminosalicylic acid (5-ASA) is a well-known pharmacological compound used to treat IBD patients. One study assessed the effects of pre-treatment with resveratrol and/or 5-ASA in HT-29 human colorectal adenocarcinoma cells after exposure to varying combinations of pro-inflammatory cytokines. At a concentration of $25 \mu \mathrm{M}$, resveratrol reduced $\mathrm{PGE}_{2}$ production, inducible NO synthase and COX-2 expression, reactive species formation ${ }^{(67)}$, and 
activated the Nrf2 pathway, inducing the expression of antioxidant and cytoprotective enzymes (haeme oxygenase 1 and glutamate

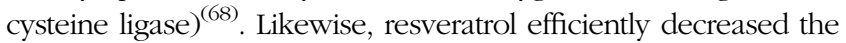
expression of phosphorylated signal transducer and activator of transcription (STAT) 1, suggesting that the Janus kinase/signal transducers and activators of transcription (JAK-STAT) pathway is a key mediator of resveratrol's anti-inflammatory activity ${ }^{(67)}$.

Mitochondrial dysfunction plays an important role in IBD pathogenesis, as oxidative stress and impaired ATP production are key players in the development and progression of the disease. Resveratrol, applied at extremely high concentrations $(440 \mu \mathrm{M})$, protected Caco- 2 cells against indomethacin-induced mitochondrial dysfunction $^{(69,70)}$. Because resveratrol has an analogous structure to rotenone (a complex I inhibitor), it has been proposed that one of the mechanisms whereby resveratrol protects against mitochondrial dysfunction is through binding to the ubiquinone site of complex I, thus inhibiting the interaction between indomethacin and rotenone ${ }^{(69)}$. In agreement, resveratrol has been shown to inhibit the mobilisation of $\mathrm{Ca}^{2+}$, the release of caspase-3, -9, and cytochrome $c$ from the mitochondria, and the induction of apoptosis in response to cytotoxic concentrations of indomethacin ${ }^{(70)}$. Therefore, resveratrol appears to potently inhibit mitochondrial dysfunction ${ }^{(71)}$ and prevent the onset of programmed cell death.

Resveratrol has also been tested in cultured cells derived from patients with chronic obstructive pulmonary disease (COPD), another disease characterised by the dysregulation of immune responses. Culpitt et al. ${ }^{(72)}$ showed that resveratrol, at very high concentrations (about $600 \mu \mathrm{m}$ ), inhibits inflammatory cytokine release from alveolar macrophages isolated from patients with COPD and alleviates inflammation.

With regards to the discrepancies in the concentrations of resveratrol used in each study, it has been shown that administration of $0.5 \mathrm{~g} / \mathrm{d}$ of resveratrol resulted in plasma concentrations ranging from $2.4 \mu \mathrm{M}$ (for a single dose) ${ }^{(30)}$ to $4.24 \mu \mathrm{M}$ (for repeated doses) ${ }^{(73)}$. Unfortunately, many in vitro studies have used relatively high concentrations of the compound. Therefore, it will be important for future research to focus on using physiological conditions $^{(46)}$ in order to verify if resveratrol, at concentrations normally found in serum, retains its antiinflammatory properties. However, resveratrol concentrations within the environment of the gastrointestinal tract vary widely among different patients and are frequently higher than those found in the blood and peripheral tissues ${ }^{(74,75)}$. Accordingly, evaluation of resveratrol uptake and analysis of its metabolites will be a crucial step in order to define the most effective concentration of resveratrol for testing in vitro ${ }^{(76)}$.

In conclusion, in vitro studies show that resveratrol, at moderate to high concentrations, can modulate inflammatory responses within intestinal cells by down-regulating NF- $\kappa \mathrm{B}$ activation and preventing mitochondrial dysfunction, providing evidence for its potential use as a novel anti-inflammatory compound in the framework of IBD.

\section{Effects of resveratrol on inflammation in animal studies}

In vivo studies using models for inflammatory intestinal chronic diseases have contributed to our understanding of the effects of resveratrol in IBD (Table 2). In a rat model of 
Table 2. Overview of the effects of resveratrol (RES) in experimental animal models of inflammatory bowel disease

\begin{tabular}{|c|c|c|c|c|}
\hline Animal model & RES dose, administration, duration & Disease induction & Effects & Reference \\
\hline Wistar rats & $\begin{array}{l}2 \text { or } 10 \mathrm{mg} / \mathrm{kg} \text { b.w. via oral } \\
\text { administration for } 7 \mathrm{~d}\end{array}$ & TNBS-induced colitis & $\begin{array}{l}\downarrow \text { Ulcerative area, } \downarrow \text { colon mass index, } \downarrow \text { colon MPO activity, } \downarrow \text { levels of } \\
\text { ICAM- } 1 \text { and VCAM- } 1 \text { in colon and serum, } \downarrow \text { levels of GSH, MDA and } \\
\text { NO in colon }\end{array}$ & Abdallah \& Ismael ${ }^{(78)}$ \\
\hline Wistar rats & $\begin{array}{l}1 \mathrm{mg} \text { each animal or } 1 \mathrm{mg} \text { in } 8 \mathrm{mg} \\
\text { nanoparticles each animal via } \\
\text { rectal administration for } 1 \text { week }\end{array}$ & TNBS-induced colitis & $\begin{array}{l}\downarrow \text { Colon histopathological injury score (only RES-loaded nanoparticles), } \downarrow \\
\text { colon weight/length (only RES-loaded nanoparticles), } \downarrow \text { colon MPO } \\
\text { activity and GSH level (only RES-loaded nanoparticles), } \downarrow \text { mRNA } \\
\text { expression levels of IL- }-1 \beta \text {, CINC- }-1, \text { MCP- } 1 \text { and ICAM- }-1 \text { in colon, } \downarrow \\
\text { mRNA expression levels of IL-6, IL- } 12 \text { and TNF-a in colon (only RES- } \\
\text { loaded nanoparticles), } \uparrow \text { mRNA expression levels of MUC-2, MUC-3, } \\
\text { TFF- } 3 \text { and villin in colon (only RES-loaded nanoparticles) }\end{array}$ & Lozano-Pérez et al. $^{(10)}$ \\
\hline Wistar rats & $\begin{array}{l}5 \text { or } 10 \mathrm{mg} / \mathrm{kg} \mathrm{b.w.} \mathrm{per} \mathrm{d} \text { via oral } \\
\text { administration for } 1-24 \mathrm{~h} \text { before } \\
\text { the induction of colitis and } 24 \mathrm{~h} \\
\text { later }\end{array}$ & TNBS-induced colitis & $\begin{array}{l}\downarrow \text { Colon macroscopic damage (only at the higher concentration), } \downarrow \text { colon } \\
\text { MPO activity (only at the higher concentration), } \downarrow \mathrm{IL}-1 \beta \text { level in colon, } \\
\leftrightarrow \mathrm{PGE}_{2} \text { level in colon, } \downarrow \mathrm{PGD}_{2} \text { level in colon (only at the higher } \\
\text { concentration) }\end{array}$ & Martín et al. ${ }^{(77)}$ \\
\hline Wistar rats & $\begin{array}{l}10 \mathrm{mg} / \mathrm{kg} \mathrm{b} \text {.w. per } \mathrm{d} \text { via oral } \\
\text { administration for } 1 \mathrm{~d} \text { before the } \\
\text { induction of colitis and } 14 \mathrm{~d} \text { later }\end{array}$ & TNBS-induced colitis & $\begin{array}{l}\downarrow \text { Colon macroscopic damage, } \downarrow \text { colon MPO activity, } \downarrow \text { TNF-a level in } \\
\text { colon, } \downarrow \text { protein expression levels of COX-1, COX-2 and NF-KB p65 in } \\
\text { colon, } \uparrow \mathrm{PGE}_{2} \text { level in colon, } \leftrightarrow \mathrm{PGD}_{2} \text { level in colon }\end{array}$ & Martín et al. ${ }^{(55)}$ \\
\hline Wistar rats & $\begin{array}{l}10 \mathrm{mg} / \mathrm{kg} \mathrm{b.w.} \mathrm{per} \mathrm{d} \mathrm{via} \\
\text { intraperitoneal injection for } 5 \mathrm{~d}\end{array}$ & TNBS-induced colitis & $\begin{array}{l}\downarrow \text { Colon microscopy score, } \downarrow \text { colon MDA level, } \leftrightarrow \text { activities of MPO, SOD } \\
\text { and CAT in colon, } \uparrow \text { colon GPX activity }\end{array}$ & Yildiz et al. ${ }^{(79)}$ \\
\hline Wistar rats & $\begin{array}{l}25 \mathrm{mg} / \mathrm{kg} \text { b.w. via oral administration } \\
\text { for } 30 \mathrm{~d}\end{array}$ & $\begin{array}{l}\text { Methotrexate-induced } \\
\text { colitis }\end{array}$ & $\begin{array}{l}\downarrow \text { Levels of MDA, GSH and 8-OH-Gua in duodenum and jejunum, } \downarrow \text { MPO } \\
\text { mRNA expression in duodenum and jejunum }\end{array}$ & Arslan et al. ${ }^{(94)}$ \\
\hline Wistar rats & $\begin{array}{l}10 \mathrm{mg} / \mathrm{kg} \text { b.w. via oral administration } \\
\text { for } 14 \mathrm{~d}\end{array}$ & $\begin{array}{l}\text { Oxazolone-induced } \\
\text { colitis }\end{array}$ & $\begin{array}{l}\downarrow \text { DAl, } \downarrow \text { colon SphK } 1 \text { activity, } \downarrow \text { colon MPO activity, } \leftrightarrow \text { colon caspase-3 } \\
\text { activity, } \downarrow \text { colon histopathological injury score }\end{array}$ & Abdin ${ }^{(96)}$ \\
\hline Fischer F344 rats & $\begin{array}{l}1 \mathrm{mg} / \mathrm{kg} \mathrm{per} \mathrm{d} \mathrm{(equivalent} \mathrm{to} \\
0.143 \mathrm{mg} / \mathrm{kg} \text { per } \mathrm{d} \text { in human } \\
\text { subjects) via chow for } 25 \mathrm{~d}\end{array}$ & DSS-induced colitis & $\begin{array}{l}\downarrow \text { Relative shortening of colon length, } \downarrow \text { colon histopathological injury } \\
\text { score, } \downarrow \text { COX-2, PTGES and PGE } 2 \text { protein levels in colon, } \downarrow \text { NO level in } \\
\text { colon, } \leftrightarrow \text { TBARS level in colon, } \leftrightarrow \text { FRAP }\end{array}$ & Larrosa et al. $^{(80)}$ \\
\hline Lewis rats & $\begin{array}{l}40 \text { or } 100 \mathrm{mg} / \mathrm{kg} \text { b.w. per d via oral } \\
\text { administration for } 28 \mathrm{~d}\end{array}$ & $\begin{array}{l}\text { PG-PS-induced } \\
\text { colitis }\end{array}$ & $\begin{array}{l}\downarrow \text { mRNA expression levels of IL-1 } 1 \beta, I L-6 \text {, TNF-a and TGF- } \beta 1 \text { in caecum } \\
\text { (only at the higher concentration), } \leftrightarrow \text { mRNA expression levels of IGF-I, } \\
\text { procollagen type I and procollagen type III in caecum }\end{array}$ & Rahal et al..$^{(93)}$ \\
\hline C57BL/6 mice & $\begin{array}{l}300 \mathrm{ppm} \text { (equivalent to } 232 \mathrm{mg} / \mathrm{d} \text { in } \\
\text { human subjects) via chow for } \\
1 \text { week before the induction of } \\
\text { colitis and } 5 \text { weeks later }\end{array}$ & DSS-induced colitis & $\begin{array}{l}\downarrow \text { Level of colon inflammation, } \downarrow \text { iNOS, COX-2 and TNF-a protein levels in } \\
\text { colon, } \downarrow \text { p53 and p53-phospho-Ser15 protein levels in colon }\end{array}$ & Cui et al. ${ }^{(98)}$ \\
\hline C57BL/6 mice & $\begin{array}{l}20 \mathrm{mg} / \mathrm{kg} \text { feed (approximately } 3 \mathrm{mg} / \\
\text { b.w.) via chow for } 3 \text { weeks }\end{array}$ & DSS-induced colitis & $\begin{array}{l}\downarrow \text { Colon weight/length, } \downarrow \text { levels of IL- } 1 \beta \text { and TNF-a in colon, } \uparrow \text { colon level } \\
\text { of IL-10, } \downarrow \text { protein expression levels of iNOS, COX-2 and PGES } 1 \text { in } \\
\text { colon, } \downarrow \text { p38 MAPK activation in colon }\end{array}$ & $\begin{array}{l}\text { Sánchez-Fidalgo } \\
\text { et al. }{ }^{\left({ }^{2}\right)}\end{array}$ \\
\hline C57BL/6 mice & $\begin{array}{l}100 \mathrm{mg} / \mathrm{kg} \text { b.w. via oral } \\
\text { administration, every } 2 \mathrm{~d} \text {, for } 10 \mathrm{~d}\end{array}$ & DSS-induced colitis & $\begin{array}{l}\uparrow \text { Colon length, } \downarrow \text { TACE mRNA expression in colon, } \uparrow \text { mRNA expression } \\
\text { levels of TIMP3 and SIRT1 in colon }\end{array}$ & Sharma et al. ${ }^{(86)}$ \\
\hline C57BL/6 mice & $\begin{array}{l}100 \mathrm{mg} / \mathrm{kg} \text { b.w. per d via oral } \\
\text { administration, every } 2 \mathrm{~d} \text {, for } \\
14 \text { weeks }\end{array}$ & DSS-induced colitis & 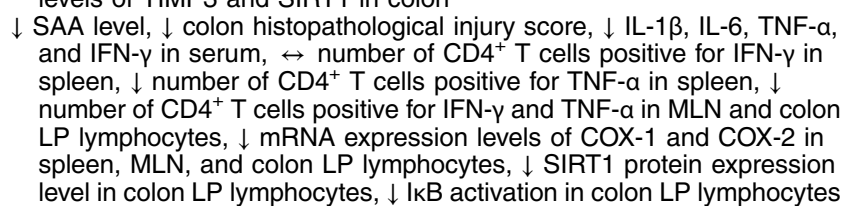 & Singh et al. ${ }^{(92)}$ \\
\hline C57BL/6 mice & $\begin{array}{l}100 \mathrm{mg} / \mathrm{kg} \text { b.w. per } \mathrm{d} \text { via oral } \\
\text { administration for } 11 \mathrm{~d}\end{array}$ & DSS-induced colitis & $\begin{array}{l}\leftrightarrow \text { Colon length, } \leftrightarrow \text { spleen weight, } \leftrightarrow \text { colon MPO activity (MPO activity } \\
\text { in female mice }<\text { MPO activity in male mice), } \leftrightarrow \text { TNF-a protein level in } \\
\text { colon }\end{array}$ & Wagnerova et al. ${ }^{(84)}$ \\
\hline BALB/c mice & $\begin{array}{l}30 \text { or } 60 \mathrm{mg} / \mathrm{kg} \text { b.w. per } \mathrm{d} \text { via oral } \\
\text { administration for } 14 \mathrm{~d}\end{array}$ & DSS-induced colitis & $\begin{array}{l}\downarrow \text { Histological disease score in colon, } \downarrow \text { colon MDA level, } \downarrow \text { colon MPO } \\
\text { activity, } \downarrow \text { activity of SOD and GPX in colon, } \downarrow \text { mRNA and protein } \\
\text { expression levels of IL- } 8 \text {, TNF-a and IFN- } \gamma \text { in colon }\end{array}$ & Yao et al. ${ }^{(81)}$ \\
\hline BALB/c mice & $\begin{array}{l}50 \text { or } 1000 \mathrm{mg} / \mathrm{kg} \text { b.w. per } \mathrm{d} \text { via oral } \\
\text { administration for } 14 \mathrm{~d}\end{array}$ & DSS-induced colitis & $\begin{array}{l}\downarrow \text { Histological disease score in colon, } \uparrow \text { relative number of Treg cells in } \\
\text { spleen (only at the higher concentration), } \downarrow \text { relative number of Th17 } \\
\text { cells in spleen }\end{array}$ & Yao et al. ${ }^{(90)}$ \\
\hline C57BL/6J mice & $\begin{array}{l}2.1 \mathrm{mg} / \mathrm{kg} \text { b.w per d (equivalent to } \\
0.143 \mathrm{mg} / \mathrm{kg} \text { per } \mathrm{d} \text { in human } \\
\text { subjects) via chow for } 21 \mathrm{~d}\end{array}$ & DSS-induced colitis & $\begin{array}{l}\leftrightarrow \text { Colon length, } \leftrightarrow \text { colon MPO activity, } \leftrightarrow \text { colon PGE } \mathrm{E}_{2} \text { level, } \downarrow \text { levels of } \\
\text { STNFR, MIP- } 1 \text { \% and CXCL9 in colon, } \leftrightarrow \text { levels of IL-6, IL-10 and GM- } \\
\text { CSF in colon, } \uparrow \text { colon level of IL-3, } \leftrightarrow \text { serum levels of haptoglobin and } \\
\text { fibrinogen }\end{array}$ & Larrosa et al. $^{(95)}$ \\
\hline
\end{tabular}




\section{N Nutrition Research Reviews}

Table 2 Continued

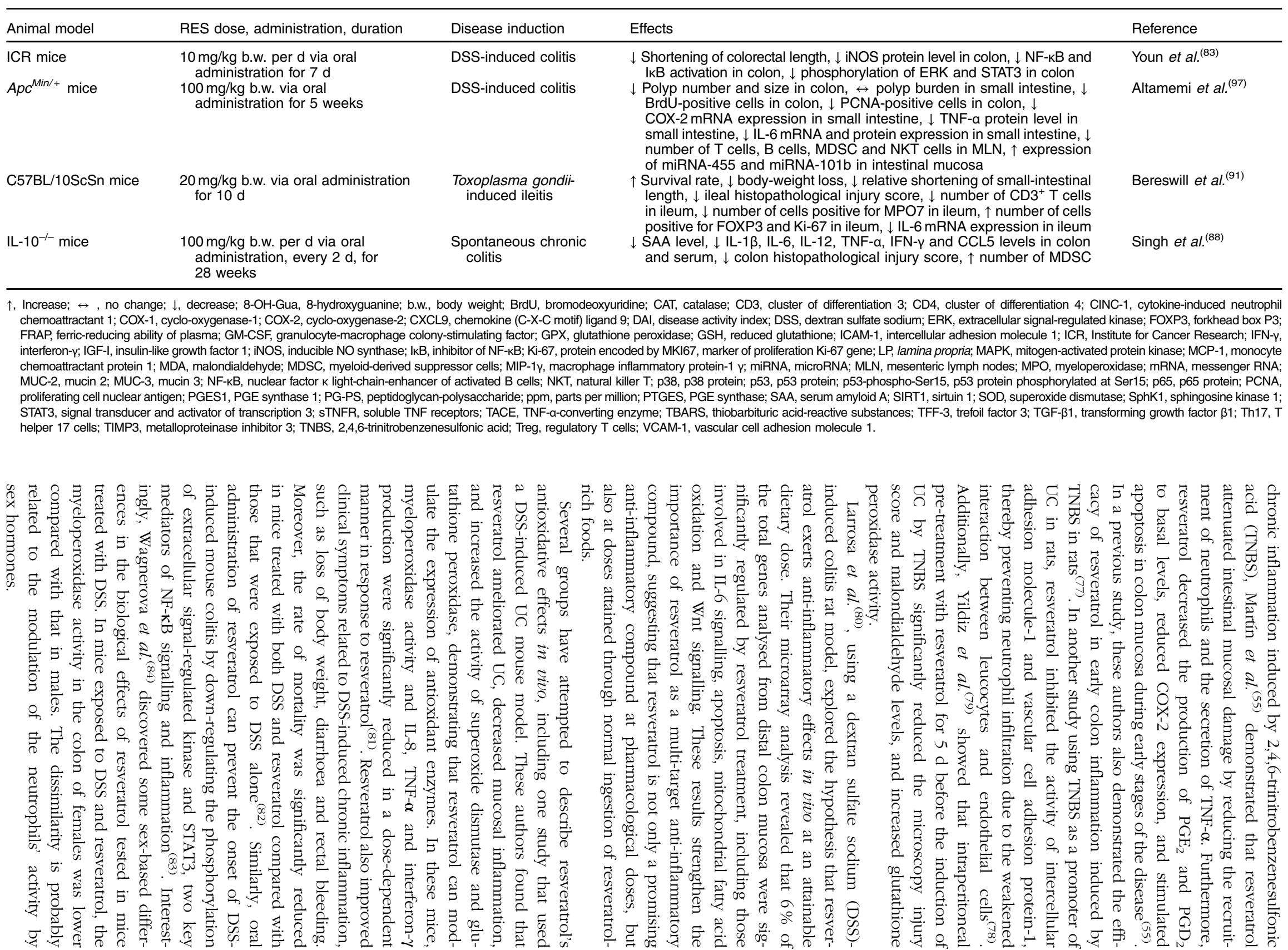


An overexpression of TNF- $\alpha$-converting enzyme (TACE) has been observed in the colon tissue of human subjects with $\mathrm{IBD}^{(85)}$, and evidence suggests that resveratrol can ameliorate the intestinal inflammation, through inhibition of TACE, in C57BL/6 mice with DSS-induced colitis ${ }^{(86)}$.

The IL- $10^{-/-}$mouse model lacks a functional version of the antiinflammatory cytokine IL-10 ${ }^{(87)}$, and has been widely used as a model of IBD. Singh et $a l .{ }^{(88)}$ showed that the oral administration of resveratrol ameliorates chronic colitis in $\mathrm{IL}-10^{-/-}$mice by the induction of myeloid-derived suppressor cells (MDSC) and lowering of both mucosal and systemic inflammatory cytokine responses. MDSC possess strong immunosuppressive activities ${ }^{(89)}$, and their modulation has potential therapeutic effects on inflammatory diseases such as IBD.

Administration of moderate to high doses of resveratrol (50 and $100 \mathrm{mg} / \mathrm{kg}$ ) was able to regulate the imbalance between Th17 and regulatory $\mathrm{T}$ (Treg) cells through reducing the number of Th17 cells and up-regulating the number of Treg cells in a DSS murine model of $\mathrm{UC}^{(90)}$.

A Toxoplasma gondii inflammation model has also been used to study the protective effects of resveratrol. Bereswill et al. ${ }^{(91)}$ observed that administration of resveratrol results in: (i) a high proliferation rate of intestinal epithelial cells in the ileal mucosa, (ii) a reduction of $\mathrm{CD}^{+} \mathrm{T}$ lymphocytes, (iii) a decrease in the levels of inflammatory cytokines such as interferon- $\gamma$ and TNF- $\alpha$ in the lamina propria, (iv) a reduction in neutrophil recruitment, and (v) a reduction in reactive species production. Furthermore, treatment with resveratrol induced changes in the gut microbiota (fewer proinflammatory enterobacteria and enterococci, and higher anti-inflammatory lactobacilli and bifidobacteria) and a decrease in bacterial translocation ${ }^{(91)}$. It also up-regulated sirtuin 1 , suppressed Th1 lymphocytes ${ }^{(92)}$, and decreased the levels of transforming growth factor $\beta 1$, all of which led to a decrease in caecal wall fibrosis ${ }^{(93)}$.

Arslan et $a l .{ }^{(94)}$ found that resveratrol is able to protect against gastrointestinal toxicity of chemotherapeutic agents such as methotrexate, demonstrating that it can reduce the oxidative stress and induce antioxidant responses in duodenal and jejunal tissues.

The application of resveratrol is limited because of its low oral bioavailability. Thus, attempts to increase its bioavailability include its encapsulation in silk fibroin nanoparticles. Administration of resveratrol nanoparticles in rats treated with TBNS and forced to undergo IBD resulted in an increased antiinflammatory effect compared with treatment with resveratrol alone, underlining a synergy between the particles and resveratrol or an enhanced anti-inflammatory effect of resveratrol. Unsurprisingly, mice treated with encapsulated resveratrol exhibited decreases in myeloperoxidase activity and expression of TNF- $\alpha$, IL-1, IL- 6 and IL-12. Thus, the use of silk fibroin nanoparticles may be an attractive strategy for the controlled release of resveratrol to target intestinal inflammation ${ }^{(10)}$. Yet another approach to increasing resveratrol bioavailability involved using a DSS murine model of inflammation. Here, resveratrol prodrugs and pro-prodrugs were applied to decrease resveratrol metabolism and to increase the availability of resveratrol in the colon. These prodrugs and pro-prodrugs restored mucosal barrier function in response to DSS and enhanced the beneficial effects of resveratrol on colon mucosa ${ }^{(95)}$. Altogether, it appears that further investigation into the potential effects of prodrugs and nanoparticles as methods to improve resveratrol's bioavailability is warranted.

Patients with IBD have an elevated risk of developing colon cancer. Abdin ${ }^{(96)}$ carried out a study to investigate the effects of resveratrol on sphingosine kinase 1 (SphK1) activity and apoptosis using a rat model of oxazolone-induced UC. SphK1 has been reported to mediate inflammatory, pro-survival and pro-proliferative signalling pathways. This study demonstrated that the activation of SphK1 plays a key role in the pathogenesis of UC and confers an increased risk of colon tumorigenesis. Furthermore, resveratrol was shown to reduce inflammation and apoptosis, possibly due to the inhibition of SphK $1^{(96)}$. Additionally, it has been shown by Ibrahim Altamemi et al. ${ }^{(97)}$ that resveratrol inhibited the formation of polyps, and reduced cell damage and proliferation of epithelial cells in the intestinal mucosa in mice exposed to DSS. In this study, resveratrol also decreased the presence of inflammatory cells (T, B and natural killer T lymphocytes) and decreased the levels of circulating cytokines. Finally, microarray analysis identified two microRNA (miRNA), miRNA-101b and miRNA-455, with anti-inflammatory properties that were up-regulated in response to resveratrol ${ }^{(97)}$. Similarly, Cui et al. ${ }^{(98)}$ observed that resveratrol improves the intestinal inflammation and down-regulates the markers of inflammation (inducible NO synthase, COX-2 and TNF- $\alpha$ ) and the sensors of inflammatory stress (p53 and p53-phospho-Ser ${ }^{15}$ ) in mice treated with DSS. Tumour incidence and multiplicity also decreased with resveratrol treatment.

In summary, resveratrol has been shown to have potent antiinflammatory effects in vivo. It decreases neutrophil infiltration in the intestinal mucosa, inhibits TNF- $\alpha$ production and NF- $\kappa \mathrm{B}$ activation, and represses intestinal tumorigenesis by regulating anti-inflammatory miRNA. Altogether, these results indicate that resveratrol could be used to prevent inflammation and reduce the risk of colon carcinogenesis in IBD.

\section{Resveratrol in human clinical trials}

Human clinical trials of the potential therapeutic, or, better, ameliorating effects of resveratrol in IBD are few (Table 3). Recently, a randomised, double-blind, placebo-controlled clinical trial evaluating the effects of resveratrol supplementation on inflammatory biomarkers and the quality of life of patients with UC was carried out. In this study, a dose of $0.5 \mathrm{~g} / \mathrm{d}$ of resveratrol was given to patients for 6 weeks. The authors observed that the plasma levels of high-sensitivity C-reactive protein in the resveratrol-treated group were reduced. Furthermore, plasma TNF- $\alpha$ and NF- $\kappa$ B p65 levels were decreased in response to resveratrol. The quality of life of these patients was improved, and the clinical colitis activity index score was significantly decreased when compared with the placebo group ${ }^{(99)}$. Furthermore, the oxidative status of patients with mild to moderate UC markedly improved - activity of superoxide dismutase and total antioxidant capacity were increased, whereas antioxidant malondialdehyde levels were decreased - in patients who were given resveratrol $^{(100)}$.

In another study, patients with colorectal cancer were given daily doses of resveratrol of 0.5 and $1 \mathrm{~g} / \mathrm{d}$ for $8 \mathrm{~d}$ before 
Table 3. Summary of findings related to resveratrol intake in patients with inflammatory bowel disease

\begin{tabular}{|c|c|c|c|c|c|c|c|}
\hline Study design & Population & $\begin{array}{c}\text { Subjects } \\
\text { (sex, } n, \text { age) }\end{array}$ & Intervention & Control/comparator & Duration & Outcomes & Reference \\
\hline Pre- and post-test & UC patients & $\begin{array}{l}\mathrm{F} \text { and } \mathrm{M}: 49 \text {, } \\
22-54 \text { years }\end{array}$ & $\begin{array}{r}\text { Resveratrol } \\
\text { capsules, } \\
500 \mathrm{mg} / \mathrm{d}\end{array}$ & - & 6 weeks & $\begin{array}{l}\downarrow \text { Plasma hs-CRP level, } \downarrow \\
\text { TNF-a level, } \downarrow \text { PBMC NF-kB } \\
\text { activation, } \uparrow \text { IBDQ-9 score, } \\
\leftrightarrow \text { SCCAl score }\end{array}$ & Samsami-Kor et al. ${ }^{(99)}$ \\
\hline Pre- and post-test & UC patients & $\begin{array}{l}\mathrm{F} \text { and } \mathrm{M}: 56 \text {, } \\
21-54 \text { years }\end{array}$ & $\begin{array}{r}\text { Resveratrol } \\
\text { capsules, } \\
500 \mathrm{mg} / \mathrm{d}\end{array}$ & - & 6 weeks & $\begin{array}{l}\uparrow \text { Plasma SOD activity, } \uparrow \\
\text { plasma TAC, } \downarrow \text { plasma MDA } \\
\text { level, } \uparrow \text { IBDQ-9 score, } \leftrightarrow \\
\text { SCCAl score }\end{array}$ & Samsamikor et al. ${ }^{(100)}$ \\
\hline
\end{tabular}

UC, ulcerative colitis; F, female; M, male; $\downarrow$, decrease; hs-CRP, high-sensitivity C-reactive protein; PBMC, peripheral blood mononuclear cells; $\uparrow$, increase; IBDQ-9, nine-item inflammatory bowel disease questionnaire; $\leftrightarrow$, no change; SCCAI, simple clinical colitis activity index; SOD, superoxide dismutase; TAC, total antioxidant capacity; MDA, malondialdehyde.

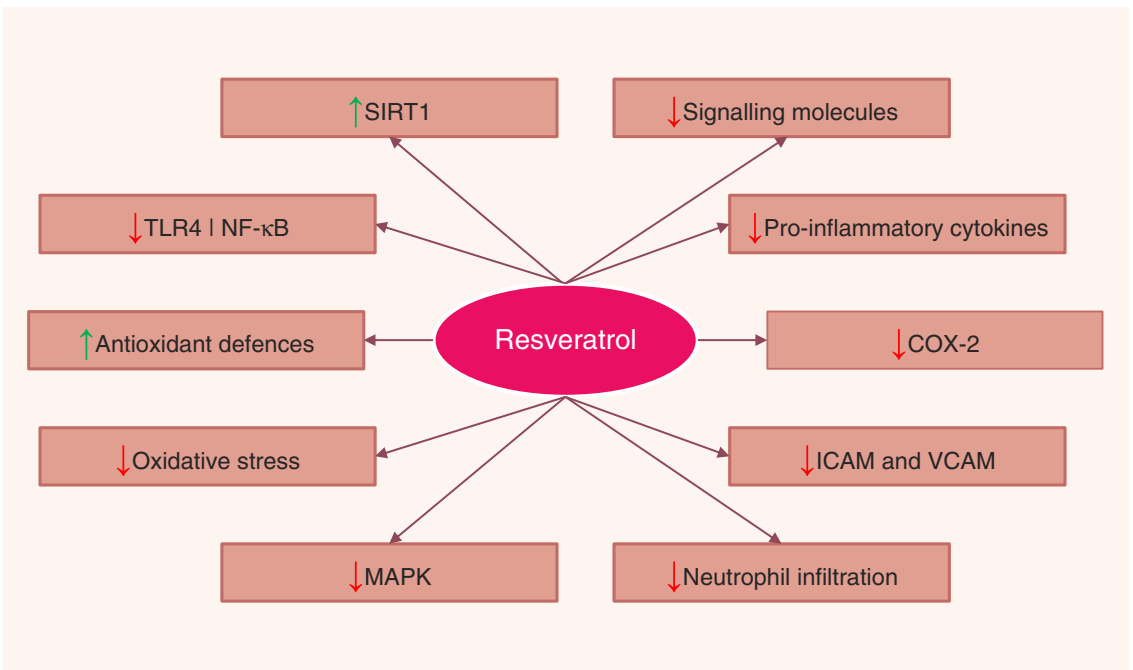

Fig. 4. Pathways regulated by resveratrol in the intestinal mucosa. SIRT1, sirtuin 1; TLR4, Toll-like receptor 4; NF-kB, nuclear factor k light-chain-enhancer of activated B cells; COX-2, cyclo-oxygenase 2; ICAM, intercellular adhesion molecule; VCAM, vascular cell adhesion molecule; MAPK, mitogen-activated protein kinase.

surgery. Interestingly, the levels of both resveratrol and its metabolites that were found in biopsy tissue samples were similar to the concentrations used in order to reduce tumorigenesis in vitro ${ }^{(75)}$.

Taken together, these studies suggest that resveratrol can improve the quality of life of patients with IBD, and decrease inflammation and oxidative stress

\section{Conclusions}

A number of in vitro and animal studies have shown that resveratrol may reduce the severity of intestinal inflammation in models of IBD. The beneficial effects of resveratrol were attributed to a variety of mechanisms that ultimately lead to the inhibition of several key components of the inflammatory cascade. The most commonly described effects were inhibition of NF- $\mathrm{KB}$ activation, decreased COX-2 expression, reduction of proinflammatory cytokines, decreased $\mathrm{PGE}_{2}$, and $\mathrm{PGD}_{2}$ levels and neutrophil infiltration, and attenuation of reactive species production. Resveratrol has also been shown to promote the reduction of bacterial translocation and to alter the intestinal microbial composition. Resveratrol also appeared to inhibit tumorigenesis by modulating a variety of signal transduction pathways and programmed cell death (Fig. 4). Nevertheless, the limited use of resveratrol metabolites in in vitro studies, the doses applied in animal models, and, most of all, the paucity of human intervention studies drastically limit the relevance of these results, as a real translation into a preventative strategy towards IBD is far from confirmed. For this reason, if resveratrol has to be kept within the list of dietary phytochemicals with a relevant anti-inflammatory effect in the framework of IBD, future research should focus on three main topics: (i) increasing the efficacy and bioavailability of resveratrol, (ii) investigating the anti-inflammatory effects of resveratrol metabolites on chronic inflammatory diseases such as IBD, while also determining possible antagonistic or synergistic interactions of these metabolites with resveratrol, and (iii) performing a number of trials in human subjects providing resveratrol as a strategic phytochemical to prevent or as a complementary treatment for IBD.

\section{Acknowledgements}

The present study was partially funded by the Italian Ministry of Education, University and Research MIUR - SIR Programme (F. D., grant number RBSI14LHMB). 
All authors contributed equally to the preparation of the paper.

There were no conflicts of interest.

\section{References}

1. Abraham C \& Cho JH (2009) Inflammatory bowel disease. N Engl J Med 361, 2066-2078.

2. Sanchez-Munoz F, Dominguez-Lopez A \& YamamotoFurusho JK (2008) Role of cytokines in inflammatory bowel disease. World J Gastroenterol 14, 4280-4288.

3. Baliga MS, Saxena A, Kaur K, et al. (2014) Chapter 50 Polyphenols in the prevention of ulcerative colitis: past, present and future. In Polyphenols in Human Health and Disease, pp. 655-663 [RR Watson, VR Preedy and S Zibadi, editors]. San Diego, CA: Academic Press.

4. Ferguson LR \& Gentschew L (2014) Inflammatory bowel disease pathogenesis. In Advanced Nutrition and Dietetics in Gastroenterology, pp. 169-179 [M Lomer, editor]. Chichester, UK: John Wiley \& Sons, Ltd.

5. Francescone R, Hou V \& Grivennikov SI (2015) Cytokines, IBD, and colitis-associated cancer. Inflamm Bowel Dis 21, 409-418.

6. Duran NE \& Hommes DW (2016) Stem cell-based therapies in inflammatory bowel disease: promises and pitfalls. Therap Adv Gastroenterol 9, 533-547.

7. Plevy SE \& Targan SR (2011) Future therapeutic approaches for inflammatory bowel diseases. Gastroenterology 140 , 1838-1846.

8. Richard JL (1987) Les facteurs de risque coronarien. Le paradoxe francais (Coronary risk factors. The French paradox). Arch Mal Coeur Vaiss 80, 17-21.

9. Catalgol B, Batirel S, Taga Y, et al. (2012) Resveratrol: French paradox revisited. Front Pharmacol 3, 141.

10. Lozano-Pérez AA, Rodriguez-Nogales A, Ortiz-Cullera V, et al. (2014) Silk fibroin nanoparticles constitute a vector for controlled release of resveratrol in an experimental model of inflammatory bowel disease in rats. Int J Nanomedicine 9, 4507-4520.

11. Stervbo U, Vang O \& Bonnesen C (2007) A review of the content of the putative chemopreventive phytoalexin resveratrol in red wine. Food Chem 101, 449-457.

12. Takaoka M (1940) The phenolic substances of white hellebore (Veratrum Grandiflorum Loes. Fill). Synthesis of resveratrol (3, 5, 4-trioxystilbene) and its derivatives. Nippon Kagaku Kaishi 61, 1067-1069.

13. King RE, Bomser JA \& Min DB (2006) Bioactivity of resveratrol. Compr Rev Food Sci Food Saf 5, 65-70.

14. Langcake P \& Pryce RJ (1976) The production of resveratrol by Vitis vinifera and other members of the Vitaceae as a response to infection or injury. Physiol Plant Pathol 9, 77-86.

15. Vian MA, Tomao V, Gallet S, et al. (2005) Simple and rapid method for cis- and trans-resveratrol and piceid isomers determination in wine by high-performance liquid chromatography using chromolith columns. J Chromatogr A 1085, 224-229.

16. Planas JM, Alfaras I, Colom H, et al. (2012) The bioavailability and distribution of trans-resveratrol are constrained by ABC transporters. Arch Biochem Biophys 527, 67-73.

17. Siemann EH \& Creasy LL (1992) Concentration of the phytoalexin resveratrol in wine. Am J Enol Vitic 43, 49-52.

18. Tomé-Carneiro J, Larrosa M, González-Sarrías A, et al. (2013) Resveratrol and clinical trials: the crossroad from in vitro studies to human evidence. Curr Pharm Des 19, 6064-6093.
19. Hurst WJ, Glinski JA, Miller KB, et al. (2008) Survey of the trans-resveratrol and trans-piceid content of cocoacontaining and chocolate products. J Agric Food Chem 56, 8374-8378.

20. Gumienna M, Lasik M \& Czarnecki Z (2011) Bioconversion of grape and chokeberry wine polyphenols during simulated gastrointestinal in vitro digestion. Int J Food Sci Nutr 62, 226-233.

21. Zhang X, Anderson J, Kaushik RS, et al. (2009) Effects of resveratrol, an important component of red wine, on intestinal cancer development. Int J Wine Res 2009, 147-153.

22. Lamuela-Raventós RM, Romero-Pérez AI, Waterhouse AL, et al. (1995) Direct HPLC analysis of cis- and transresveratrol and piceid isomers in Spanish red Vitis vinifera wines. J Agric Food Chem 43, 281-283.

23. Romero-Pérez AI, Ibern-Gómez M, Lamuela-Raventós RM, et al. (1999) Piceid, the major resveratrol derivative in grape juices. J Agric Food Chem 47, 1533-1536.

24. Moreno-Labanda JF, Mallavia R, Pérez-Fons L, et al. (2004) Determination of piceid and resveratrol in Spanish wines deriving from Monastrell (Vitis vinifera L.) grape variety. J Agric Food Chem 52, 5396-5403.

25. Ribeiro de Lima MT, Waffo-Téguo P, Teissedre PL, et al. (1999) Determination of stilbenes (trans-astringin, cisand trans-piceid, and cis- and trans-resveratrol) in Portuguese wines. J Agric Food Chem 47, 2666-2670.

26. Jenner AM, Rafter J \& Halliwell B (2005) Human fecal water content of phenolics: the extent of colonic exposure to aromatic compounds. Free Radic Biol Med 38, 763-772.

27. Ahmed Nasef N, Mehta S \& Ferguson LR (2014) Dietary interactions with the bacterial sensing machinery in the intestine: the plant polyphenol case. Front Genet 5, 64.

28. Danesi F \& Ferguson LR (2017) Could pomegranate juice help in the control of inflammatory diseases? Nutrients $\mathbf{9}$, E958.

29. Walle T (2011) Bioavailability of resveratrol. Ann N Y Acad Sci 1215, 9-15.

30. Boocock DJ, Faust GE, Patel KR, et al. (2007) Phase I dose escalation pharmacokinetic study in healthy volunteers of resveratrol, a potential cancer chemopreventive agent. Cancer Epidemiol Biomarkers Prev 16, 1246-1252.

31. Henry C, Vitrac X, Decendit A, et al. (2005) Cellular uptake and efflux of trans-piceid and its aglycone trans-resveratrol on the apical membrane of human intestinal Caco- 2 cells. J Agric Food Chem 53, 798-803.

32. Henry-Vitrac C, Desmoulière A, Girard D, et al. (2006) Transport, deglycosylation, and metabolism of trans-piceid by small intestinal epithelial cells. Eur J Nutr 45, 376-382.

33. Chukwumah Y, Walker L, Vogler B, et al. (2011) In vitro absorption of dietary trans-resveratrol from boiled and roasted peanuts in Caco-2 cells. J Agric Food Chem 59, 12323-12329.

34. Kaldas MI, Walle UK \& Walle T (2003) Resveratrol transport and metabolism by human intestinal Caco- 2 cells. J Pharm Pharmacol 55, 307-312.

35. Patel KR, Andreadi C, Britton RG, et al. (2013) Sulfate metabolites provide an intracellular pool for resveratrol generation and induce autophagy with senescence. Sci Transl Med 5, $205 \mathrm{ra} 133$.

36. Maier-Salamon A, Hagenauer B, Wirth M, et al. (2006) Increased transport of resveratrol across monolayers of the human intestinal Caco- 2 cells is mediated by inhibition and saturation of metabolites. Pharm Res 23, 2107-2115.

37. Andlauer W, Kolb J, Siebert K, et al. (2000) Assessment of resveratrol bioavailability in the perfused small intestine of the rat. Drugs Exp Clin Res 26, 47-55. 
38. Gao S, Basu S, Yang G, et al. (2013) Oral bioavailability challenges of natural products used in cancer chemoprevention. Prog Chem 25, 1553-1574.

39. Englund G, Rorsman F, Rönnblom A, et al. (2006) Regional levels of drug transporters along the human intestinal tract: co-expression of ABC and SLC transporters and comparison with Caco-2 cells. Eur J Pharm Sci 29, 269-277.

40. van de Wetering K, Burkon A, Feddema W, et al. (2009) Intestinal breast cancer resistance protein (BCRP)/Bcrp1 and multidrug resistance protein 3 (MRP3)/Mrp3 are involved in the pharmacokinetics of resveratrol. Mol Pharmacol 75, 876-885.

41. Lançon A, Delmas D, Osman H, et al. (2004) Human hepatic cell uptake of resveratrol: involvement of both passive diffusion and carrier-mediated process. Biochem Biophys Res Commun 316, 1132-1137.

42. Juan ME, González-Pons E \& Planas JM (2010) Multidrug resistance proteins restrain the intestinal absorption of trans-resveratrol in rats. $J$ Nutr 140, 489-495.

43. Lançon A, Hanet N, Jannin B, et al. (2007) Resveratrol in human hepatoma HepG2 cells: metabolism and inducibility of detoxifying enzymes. Drug Metab Dispos 35, 699-703.

44. Maier-Salamon A, Hagenauer B, Reznicek G, et al. (2008) Metabolism and disposition of resveratrol in the isolated perfused rat liver: role of Mrp2 in the biliary excretion of glucuronides. J Pharm Sci 97, 1615-1628.

45. Jannin B, Menzel M, Berlot JP, et al. (2004) Transport of resveratrol, a cancer chemopreventive agent, to cellular targets: plasmatic protein binding and cell uptake. Biochem Pharmacol 68, 1113-1118.

46. Aragonès G, Danesi F, Del Rio D, et al. (2017) The importance of studying cell metabolism when testing the bioactivity of phenolic compounds. Trends Food Sci Technol doi: 10.1016/j.tifs.2017.02.001.

47. Del Rio D, Rodriguez-Mateos A, Spencer JP, et al. (2013) Dietary (poly)phenolics in human health: structures, bioavailability, and evidence of protective effects against chronic diseases. Antioxid Redox Signal 18, 1818-1892.

48. Ramanan D \& Cadwell K (2016) Intrinsic defense mechanisms of the intestinal epithelium. Cell Host Microbe 19, 434-441.

49. Lee SH (2015) Intestinal permeability regulation by tight junction: implication on inflammatory bowel diseases. Intest Res 13, 11-18.

50. Salim SY \& Söderholm JD (2011) Importance of disrupted intestinal barrier in inflammatory bowel diseases. Inflamm Bowel Dis 17, 362-381.

51. Miner-Williams WM \& Moughan PJ (2016) Intestinal barrier dysfunction: implications for chronic inflammatory conditions of the bowel. Nutr Res Rev 29, 40-59.

52. Kühl AA, Erben U, Kredel LI, et al. (2015) Diversity of intestinal macrophages in inflammatory bowel diseases. Front Immunol 6, 613

53. Danese S \& Fiocchi C (2016) Endothelial cell-immune cell interaction in IBD. Dig Dis 34, 43-50.

54. Deniz M, Cetinel S \& Kurtel H (2004) Blood flow alterations in TNBS-induced colitis: role of endothelin receptors. Inflamm Res 53, 329-336.

55. Martín AR, Villegas I, Sánchez-Hidalgo M, et al. (2006) The effects of resveratrol, a phytoalexin derived from red wines, on chronic inflammation induced in an experimentally induced colitis model. Br J Pharmacol 147, 873-885.

56. Clark RA, Epperson TK \& Valente AJ (2004) Mechanisms of activation of NADPH oxidases. Ipn J Infect Dis 57, S22-S23.

57. Piechota-Polanczyk A \& Fichna J (2014) Review article: the role of oxidative stress in pathogenesis and treatment of inflammatory bowel diseases. Naunyn Schmiedebergs Arch Pharmacol 387, 605-620.

58. Danese S, Sans M \& Fiocchi C (2004) Inflammatory bowel disease: the role of environmental factors. Autoimmun Rev 3, 394-400.

59. Schottelius AJ \& Dinter H (2006) Cytokines, NF-кB, microenvironment, intestinal inflammation and cancer. Cancer Treat Res 130, 67-87.

60. Kovacic P \& Somanathan R (2014) Inflammation and antiinflammatory agents - reactive oxygen species and toxicity. In Systems Biology of Free Radicals and Antioxidants pp. 3197-3216 [I Laher, editor]. Berlin and Heidelberg: Springer Berlin Heidelberg.

61. Abraham C \& Cho J (2009) Interleukin-23/Th17 pathways and inflammatory bowel disease. Inflamm Bowel Dis $\mathbf{1 5}$, 1090-1100.

62. McGovern D \& Powrie F (2007) The IL23 axis plays a key role in the pathogenesis of IBD. Gut 56, 1333-1336.

63. Danesi F, Philpott M, Huebner C, et al. (2010) Food-derived bioactives as potential regulators of the IL-12/IL-23 pathway implicated in inflammatory bowel diseases. Mutat Res 690, 139-144.

64. Cianciulli A, Calvello R, Cavallo P, et al. (2012) Modulation of NF- $\mathrm{KB}$ activation by resveratrol in LPS treated human intestinal cells results in downregulation of PGE2 production and COX-2 expression. Toxicol In Vitro 26, 1122-1128.

65. Panaro MA, Carofiglio V, Acquafredda A, et al. (2012) Antiinflammatory effects of resveratrol occur via inhibition of lipopolysaccharide-induced NF- $\mathrm{\kappa B}$ activation in Caco-2 and SW480 human colon cancer cells. Br J Nutr 108, 1623-1632.

66. Romier B, Van De Walle J, During A, et al. (2008) Modulation of signalling nuclear factor- $\mathrm{KB}$ activation pathway by polyphenols in human intestinal Caco-2 cells. Br J Nutr 100, 542-551.

67. Serra D, Rufino AT, Mendes AF, et al. (2014) Resveratrol modulates cytokine-induced Jak/STAT activation more efficiently than 5-aminosalicylic acid: an in vitro approach. PLoS One 9, e109048.

68. Serra D, Almeida LM \& Dinis TC (2016) Anti-inflammatory protection afforded by cyanidin-3-glucoside and resveratrol in human intestinal cells via Nrf2 and PPAR- $\gamma$ : comparison with 5-aminosalicylic acid. Chem Biol Interact 260, 102-109.

69. Carrasco-Pozo C, Mizgier ML, Speisky H, et al. (2012) Differential protective effects of quercetin, resveratrol, rutin and epigallocatechin gallate against mitochondrial dysfunction induced by indomethacin in Caco-2 cells. Chem Biol Interact 195, 199-205.

70. Carrasco-Pozo C, Pastene E, Vergara C, et al. (2012) Stimulation of cytosolic and mitochondrial calcium mobilization by indomethacin in Caco- 2 cells: modulation by the polyphenols quercetin, resveratrol and rutin. Biochim Biophys Acta 1820, 2052-2061.

71. Ungvari Z, Sonntag WE, de Cabo R, et al. (2011) Mitochondrial protection by resveratrol. Exerc Sport Sci Rev 39, 128-132.

72. Culpitt SV, Rogers DF, Fenwick PS, et al. (2003) Inhibition by red wine extract, resveratrol, of cytokine release by alveolar macrophages in COPD. Thorax 58, 942-946.

73. Brown VA, Patel KR, Viskaduraki M, et al. (2010) Repeat dose study of the cancer chemopreventive agent resveratrol in healthy volunteers: safety, pharmacokinetics, and effect on the insulin-like growth factor axis. Cancer Res $\mathbf{7 0}$, 9003-9011. 
74. Singh CK, Ndiaye MA \& Ahmad N (2015) Resveratrol and cancer: Challenges for clinical translation. Biochim Biophys Acta 1852, 1178-1185.

75. Patel KR, Brown VA, Jones DJ, et al. (2010) Clinical pharmacology of resveratrol and its metabolites in colorectal cancer patients. Cancer Res 70, 7392-7399.

76. Chachay VS, Kirkpatrick CM, Hickman IJ, et al. (2011) Resveratrol - pills to replace a healthy diet? $\mathrm{Br} J$ Clin Pharmacol 72, 27-38.

77. Martín AR, Villegas I, La Casa C, et al. (2004) Resveratrol, a polyphenol found in grapes, suppresses oxidative damage and stimulates apoptosis during early colonic inflammation in rats. Biochem Pharmacol 67, 1399-1410.

78. Abdallah DM \& Ismael NR (2011) Resveratrol abrogates adhesion molecules and protects against TNBS-induced ulcerative colitis in rats. Can J Physiol Pharmacol 89, 811-818.

79. Yildiz G, Yildiz Y, Ulutas PA, et al. (2015) Resveratrol pretreatment ameliorates TNBS colitis in rats. Recent Pat Endocr Metab Immune Drug Discov 9, 134-140.

80. Larrosa M, Yañéz-Gascón MJ, Selma MV, et al. (2009) Effect of a low dose of dietary resveratrol on colon microbiota, inflammation and tissue damage in a DSS-induced colitis rat model. J Agric Food Chem 57, 2211-2220.

81. Yao J, Wang JY, Liu L, et al. (2010) Anti-oxidant effects of resveratrol on mice with DSS-induced ulcerative colitis. Arch Med Res 41, 288-294.

82. Sánchez-Fidalgo S, Cárdeno A, Villegas I, et al. (2010) Dietary supplementation of resveratrol attenuates chronic colonic inflammation in mice. Eur J Pharmacol 633, 78-84.

83. Youn J, Lee JS, Na HK, et al. (2009) Resveratrol and piceatannol inhibit iNOS expression and NF- $\mathrm{\kappa B}$ activation in dextran sulfate sodium-induced mouse colitis. Nutr Cancer 61, 847-854.

84. Wagnerova A, Babickova J, Liptak R, et al. (2017) Sex differences in the effect of resveratrol on DSS-induced colitis in mice. Gastroenterol Res Pract 2017, 8051870.

85. Freour T, Jarry A, Bach-Ngohou K, et al. (2009) TACE inhibition amplifies TNF- $\alpha$-mediated colonic epithelial barrier disruption. Int J Mol Med 23, 41-48.

86. Sharma M, Mohapatra J, Wagh A, et al. (2014) Involvement of TACE in colon inflammation: a novel mechanism of regulation via SIRT-1 activation. Cytokine 66, 30-39.

87. Kühn R, Löhler J, Rennick D, et al. (1993) Interleukin-10deficient mice develop chronic enterocolitis. Cell 75, 263-274.

88. Singh UP, Singh NP, Singh B, et al. (2012) Role of resveratrol-induced $\mathrm{CD}_{11 \mathrm{~b}^{+}} \mathrm{Gr}-1^{+}$myeloid derived suppressor cells (MDSCs) in the reduction of $\mathrm{CXCR}^{+}{ }^{+} \mathrm{T}$ cells and amelioration of chronic colitis in IL- $10^{-/-}$mice. Brain Behav Immun 26, 72-82.
89. Haile LA, von Wasielewski R, Gamrekelashvili J, et al. (2008) Myeloid-derived suppressor cells in inflammatory bowel disease: a new immunoregulatory pathway. Gastroenterology 135, 871-881.

90. Yao J, Wei C, Wang JY, et al. (2015) Effect of resveratrol on Treg/Th17 signaling and ulcerative colitis treatment in mice. World J Gastroenterol 21, 6572-6581.

91. Bereswill S, Muñoz M, Fischer A, et al. (2010) Antiinflammatory effects of resveratrol, curcumin and simvastatin in acute small intestinal inflammation. PLoS One $\mathbf{5}$, e15099.

92. Singh UP, Singh NP, Singh B, et al. (2010) Resveratrol (trans-3,5,4'-trihydroxystilbene) induces silent mating type information regulation-1 and down-regulates nuclear transcription factor- $\kappa \mathrm{B}$ activation to abrogate dextran sulfate sodium-induced colitis. J Pharmacol Exp Ther 332, 829-839.

93. Rahal K, Schmiedlin-Ren P, Adler J, et al. (2012) Resveratrol has antiinflammatory and antifibrotic effects in the peptidoglycan-polysaccharide rat model of Crohn's disease. Inflamm Bowel Dis 18, 613-623.

94. Arslan A, Ozcicek F, Keskin Cimen F, et al. (2015) Protective effect of resveratrol against methotrexateinduced oxidative stress in the small intestinal tissues of rats. Int J Clin Exp Med 8, 10491-10500.

95. Larrosa M, Tomé-Carneiro J, Yáñez-Gascón MJ, et al. (2010) Preventive oral treatment with resveratrol pro-prodrugs drastically reduce colon inflammation in rodents. $J$ Med Chem 53, 7365-7376.

96. Abdin AA (2013) Targeting sphingosine kinase 1 (SphK1) and apoptosis by colon-specific delivery formula of resveratrol in treatment of experimental ulcerative colitis in rats. Eur J Pharmacol 718, 145-153.

97. Altamemi I, Murphy EA, Catroppo JF, et al. (2014) Role of microRNAs in resveratrol-mediated mitigation of colitisassociated tumorigenesis in $A p c^{\mathrm{Min} /+}$ mice. J Pharmacol Exp Ther 350, 99-109.

98. Cui X, Jin Y, Hofseth AB, et al. (2010) Resveratrol suppresses colitis and colon cancer associated with colitis. Cancer Prev Res 3, 549-559.

99. Samsami-Kor M, Daryani NE, Asl PR, et al. (2015) Anti-inflammatory effects of resveratrol in patients with ulcerative colitis: a randomized, double-blind, placebocontrolled pilot study. Arch Med Res 46, 280-285.

100. Samsamikor M, Daryani NE, Asl PR, et al. (2016) Resveratrol supplementation and oxidative/anti-oxidative status in patients with ulcerative colitis: a randomized, double-blind, placebo-controlled pilot study. Arch Med Res 47, 304-309. 